Sahar Abdel Khaleq Abbass

\title{
Upsurges of Metatheatrical Dramaturgy in Heather Raffo's 9 Parts of Desire
}

\author{
By \\ Sahar Abdel Khaleq Abbass \\ Assistant Professor of English Literature (مدرس) \\ Hurghada Faculty of Education \\ Abstract \\ South Valley University, Egypt
}

The primary concern of this paper is to focus on the use of metatheatre in 9 Parts of Desire (2006), a play written by the American Iraqi dramatist, Heather Raffo. The word "metatheatre" or "metadrama" was first coined in 1963 by Lionel Abel, who introduced a new form of drama that breaks with the modernist conventions and techniques. A discussion of the metatheatrical elements in 9 Parts of Desire enlightens interpretive potentials beyond the realm of its often-discussed traumatic nature. 9 Parts of Desire is a play that dramatizes the stories of nine Iraqi women. The narratives of these women are taken into limelight on Raffo's versatile theatre, as the structure of her play breaks with the norms of traditional theatre. According to Lionel Abel, the word "metatheatre" is used to describe self- conscious theatre, one that demonstrates its own theatricality. Raffo's artful self-reflexive and self-conscious devices helped portray a lively vision of both Iraqi women's solid deep bonds to Iraq, and the US invasion's impact on their lives. Meanwhile, Raffo managed to stimulate her audience/reader to think not only of the embedded meaning of the play's perspectives but also of its crafty dramaturgy. Therefore, this paper explores how the employment of specific metatheatrical techniques in 9 Parts of Desire has helped enlighten the playwright's unique vision of the emotional, cultural, and historical dimensions of her characters and their theatrical awareness, as well.

Key words: 9 Parts of Desire, Heather Raffo, Metatheatre, Selfconscious Theatre 


\section{Upsurges of Metatheatrical Dramaturgy in Heather Raffo's 9 Parts of Desire}

\section{ملخص البحث}

يتناول البحث جانب الميتا مسرح في مسرحية تسعة أجزاء من الرغبة (2006) التي قامت بتأليفها الكاتبة المسرحية الأميركية من أصل عراقي، هيذر رافو. و وجدير بالذكر أن أول من هن أطلق لفظ "الميتا مسرح" على هذا النوع من الكتابة المسرحية في عام 1963، هو الناقد المسرحي الأميركي لاينل إييل.

إن مسرحية تسعة أجزاء من الرغبة تعالج تجارب تسع نماذج مختلفة من النساء

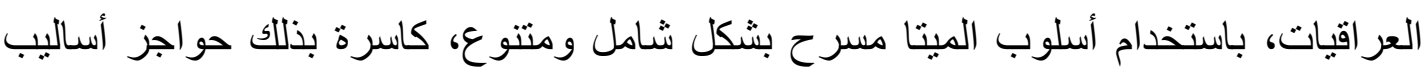
الكتابة المسرحية التقليدية. وطبقا للناقد المسرحي لاينل إييل، فإن كلمة "ميناثيتر" أو الميتا

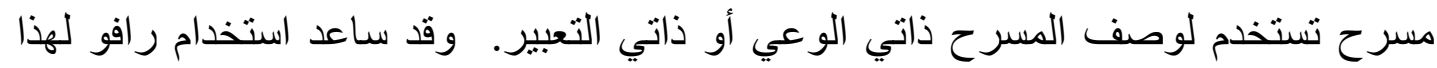

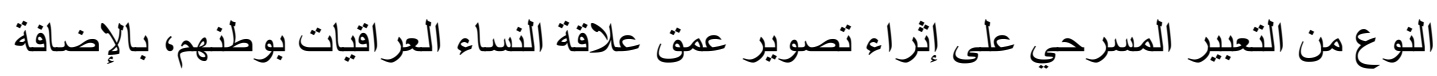

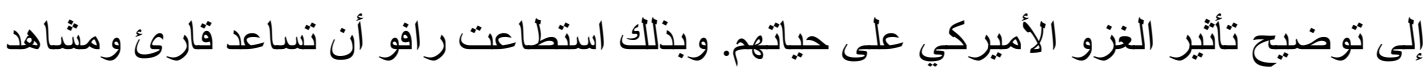

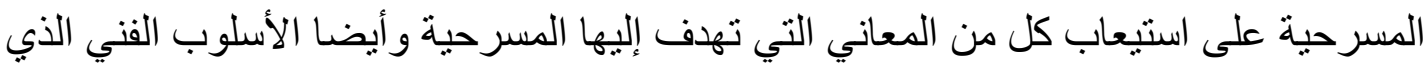
تم حياكتها باه.

لذللك فإن الهذف من هذا البحث هو إلقاء الضوء على استخدام رافو للأسلوب الدرامي

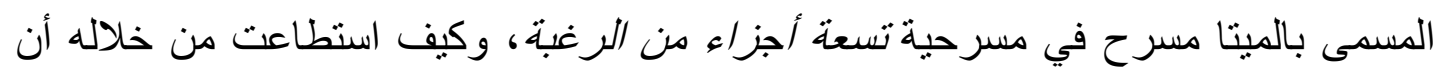

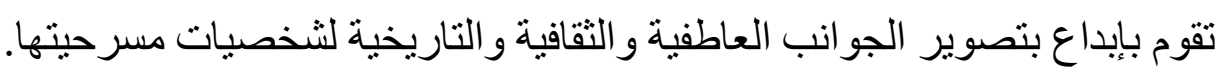

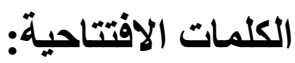
تسعة أجزاء من الرغبة، هيذر رافو، الميتا مسرح، المسرح ذاتي الوعي 


\section{Introduction}

The aim of this research paper is to explore how in 9 Parts of Desire, Raffo sets aside the common dramaturgical techniques of theatre and employs metatheatrical techniques to depict her unique perspective of the play's characters' ties to Iraqi culture. 9 Parts of Desire has more than one level of interpretations. This paper, however, will only focus on Raffo's employment of metatheatre in the play. Though Raffo's use of metatheatrical devices in the play is varied and versatile, yet this study will only select the most recognizable metatheatrical features in the light of Richard Hornby's perception of metatheatre. Raffo's artistry of this multidimensional device is made clear through examining her implementation of techniques such as real-reference to places, names and languages, ceremonies and rituals, role- playing within the play, and self- reflectively theatrical scenes. These techniques are sometimes separately employed in the play or juxtaposed with one another, in a way that abolishes the boundary between the audience and characters, creating the required evenhanded reception world for the audience.

Although recognized as popular only in the mid-twentieth century, practices of a distinctly metatheatrical nature pierced the works of numerous modern and contemporary dramatists. The term metatheatre began to extensively capture the attention in the 1960s, after the word "meta" had marked unpreceded importance for literary men. As Brian Crow (2002) maintains, "Metatheatre or the capacity of stage text and performance to refer to and comment on its own nature as an artistic medium has been an age-long adaptation" (p. 133) in theatrical works. In Oxford Dictionary of Current English, the word 'meta' means: "behind, after or beyond". Thus, a play is identified as metatheatrical if it employs other devices on theatre than the narrative itself, or in other words a series of reflexive dramatic strategies, which have dramaturgical functions. These devices help "develop the story [and] provide an underlying way of thinking about life and the art of theatre itself"' (Liang, 2010, p. 100).

The formulation of the notion "metatheatre" or "metadrama" is indebted to the American playwright and theatre critic, Lionel Abel who was the first to coin it in 1963, in his Metatheatre: A New View of Dramatic Form. Explaining how the word metatheatre had been widely used all over the world, Abel (2003, p. v) asserts that "metatheatre at the very least, has added a word to the language with which we now talk of theatre". He maintains that metatheatrical plays "have one common character: all of them are theatre pieces about life seen as already theatricalized" (Abel, 2003, p. vi). Then he adds that "persons appearing on the stage in these plays are there simply because they ... 
already knew they are dramatic. They are aware of their own theatricality" (Abel, 2003, p. vi). However, the understanding of metatheatre has been deepened and broadened and is no longer confined to some limited identification. As Patrice Pavis (1998) clarifies, in his Dictionary of the theatre, "metatheatricality is a fundamental characteristic of any theatrical communication" (p. 210). "All that is required" for a play to be metatheatrical " is that the represented reality appears to be one that is already theatrical, as in plays in which the main theme is life as theatre ... [and] where the dividing line between play and real life is erased" (Pavis, 1998, p. 210). "It deliberately marks the boundaries the conventional theatre tries to hide and constantly reminds the audience of the relationship between performance and reality" (Liang, 2010, p. 100). Millie Barranger also suggests that "The metatheatrical play... uses the stage-as-stage to present life as theatricality" and "has as one of its goals an examination of the distinctions between art and life" (as cited in Liang, 2010, p. 100). Metatheatre is that kind of literature with self- awareness that helps unlimited capacities of theatre making and which as Crow (2002) suggests is able to "anatomize oppression and injustice and to celebrate the capacity of theatre and the theatrical to function as modes of survival, resistance, and even... optimistic moments" (p. 134). In fact metatheatrical devices can be used in theatre to feature different ideological themes of a play. A good example of this is Albert Brecht's epic theatre which was the first to systematically use metatheatrical techniques for political purposes. In 9 Parts of Desire, Heather Raffo, has also used metatheatre as a device to portray the play's characters' resistance and heritage, thus emphasizing the play's political and historical dimensions.

Richard Hornby's Drama, Metadrama and Perception (1986), is considered the most influential book on metatheatrical views and practices. In his inspiring work, Hornby expanded the meaning of "Metatheatre", by identifying more characteristics and devices to a metatheatrical play. He perceives metatheatre as "drama about drama". To him, metatheatre happens "whenever the subject of a play turns out to be, in some sense, drama itself" (Hornby, 1986, p. 31). In his book, Hornby identifies five different techniques of metatheatre, which sometimes blend with each other. These devices are "the play within the play", "the ceremony within the play", "role playing within the role", "literary and real-life reference", and "self- reference" (Hornby, 1986, p. 32). He maintains that they have "no truth in and of themselves, but rather a means of discovering truth" of life (Hornby, 1986, p. 32). Hornby's classification of different forms and types of 
metatheatre in his book is helpful in analyzing 9 Parts of Desire. Moreover, his application and assemblage of his idea of metatheatrical drama and culture in his book, reflect as Nadia Anwar suggests, "a wide range of cultural, literary, artistic, sociopolitical, and ideological influences that shape a particular piece of performance" (2016, para. 4).

\subsection{Parts of Desire's production and perception}

Heather Raffo is an American dramatist, and performer. She was born in 1970 in Mosul, Iraq to an Iraqi father and an American mother. Her parents moved to the United States, early in the seventies, where she grew up and lived in Michigan. Raffo received a BA from the University of Michigan, and an MFA from the University of San Diego. Her achievements include Noura (2018), 9 Parts of Desire (2006), Sounds of Desire, a concert (2009). Raffo also participated in writing The Middle East in Pieces, a play written in 2006. Being an American with an Arabic origin had a great impact on shaping Raffo's life. She maintains,

The first Gulf War was the most defining moment of my life. I was in school at the University of Michigan. I remember watching many of my fellow students at the bar cheering the war as it played out on TV, while I was worried if my family in Baghdad was even going to survive. Over a decade later, I think Americans are deeply questioning their place in Iraq, and wondering about its history: Who are its people? What do they want? (Raffo, 2011, para. 7)

Raffo's interest in Iraqi heritage was awakened during the first Gulf War. So, she began writing her play 9 Parts of Desire in 1993, as a university thesis project. In 2006 she had this play published. Raffo gained great fame after performing her significant role in this onecharacter play, which has become one of the most appraised Iraqi American drama. It is a one-act play, written in 2003 for the stage and released in 2006. This play was not only a success on Broadway, where it had been performed for almost nine months, but has also been running around the U.S. and all over the world for more than ten years. For its performance in London, The Independent recurrently chose it as one of London's "Five Best Plays". The play was also described by John Lahr as "an example of how art can remake the world" (2004, para. 3). For her distinguished playwriting and creation of the play, Raffo won several awards including Susan Smith Blackburn and Lucille Lortel Awards in 2005. She was also repeatedly nominated for other drama writing awards. The response to the play drew much media attention to 
Raffo, as she has given several public appearances and interviews on American television shows.

Raffo has never forgotten her family roots. In 1993, she paid a visit to her father's relatives in Baghdad, Iraq, a visit she calls a "lifechanging trip" (Raffo, 2006, p. ix). During this visit, she was inspired to write 9 Parts of Desire 2 after she saw a haunting painting in a museum in Baghdad, "of a nude woman clinging to a barren tree" (Raffo, 2006, p. $x)$. This painting was created by Iraqi famous artist Layla Al Attar, whose name has turned to be one of the main personalities in the play. Trying to get to a deeper understanding of the underlying meaning of the painting, Raffo, for ten years, had informally interviewed several Iraqi women of different ages, and various social conditions. She "listened deeply to what each woman said, what she wanted to say but couldn't, and what she never knew how to say" (Raffo, 2006, p. x). A decade later, Raffo finished writing 9 Parts of Desire focusing on these Iraqi women's collective experience.

\section{Metatheatre in 9 Parts of Desire}

Although 9 Parts of Desire has received diverse interpretations as a socio-political play that mirrors trauma, testimony, stereotyping or even feminism, yet this paper will focus only on its interpretation as a metatheatrical play. A closer reading of 9 Parts of Desire demonstrates that it is replete with metatheatrical devices that the playwright used to "provide an underlying way of thinking about the dimensions of awareness of the stories of her characters" (Pavis, 1998, p. 32). These characters are designed as distinct dramatic figures in the sense of experience, and social positions, which required a kind of metatheatre that can attract the audience's attention to the play.

9 Parts of Desire dramatizes the narratives of nine Iraqi women, with different identities, and different living conditions, through deploying intertwined metatheatrical elements. These narratives are mixtures of the stories of Iraqi women that Raffo kept on interviewing for almost ten years. The first character the reader meets in the opening of the play is Mullaya, a professional mourner, hired "to lead call and response with women mourning at funerals" (Raffo, 2006, p. 3). Layal, an artist, is another character who is narrating her experience under the protection of Iraq's old regime. Then, there's Amal, a Bedouin who has been for years, in search for genuine love. There is also Huda, an Iraqi exile living in London for decades now. An unnamed Iraqi doctor, is also portrayed, recounting the miseries of the Iraqi casualties of the war. Raffo did not ignore children in the play; she personifies Samira, a 9- 
year-old girl, who ironically, speaks English better than most of the characters. The little girl contributes with telling the agony of having a restricted way of life, after losing her father and then her grandparents during different wars. Meanwhile, Umm Ghada is "a woman of great stillness and pride, peaceful and dispassionate" (Raffo, 2006, p. 28). She is a mother who speaks out her loss of all her children during the Amiriyyia bomb Shelter, which has changed into a mass grave. The reader also meets the Un-named American, an Iraqi woman living in America, while the rest of her family lives in Iraq. The eldest character in the play is Nanna, a seventy-year-old street dealer, who had lived through Iraq's 23 revolutions, and earns her living through "selling anything she can on the street corner" (Raffo, 2006, p. 41). Rather than focusing on one specific narrative, Raffo has each of these characters, with her own story, share in illuminating the full scope of Iraq's historical heritage and present troubled events.

In her 'Production Notes', Raffo contends that she "would encourage those doing a production of 9 Parts of Desire to never think of these women as victims ... but rather explore the resilience, ambitions, warmth, humor, integrity, and the ancient history of the Iraqi women depicted" (Raffo, 2006, p. 71). Addressing the Western audience/reader, Raffo portrays the truth of Iraqi women's identity after suffering from two wars. Hence, Raffo sided away from the traditional style of writing, in that she addresses the audience with innovatively metatheatrical techniques, that adds multidimensional visions to her work. Therefore, she managed to enhance the audience to perceive "the play on two levels, both as affectation of reality and as an unreal piece of dramatic fiction" (Taiwo, 2014, p. 147).

\section{1. Literary and Real-life References:}

A critical focus on one of the play's metatheatrical features, 'literary and real-life references' allows us to better understand the playwright's perspective of the cultural heritage of Iraq. Through referring to Iraqi great history and culture, Raffo wanted the audience of her play to relate between Iraq's current situation and its great civilization. Hornby views that including literary or real-life references for the purpose of understanding the cultural meaning of a play is metatheatrical. He considers that literary reference means a "direct, conscious allusion to specific works ... that are recent and popular... Real-life reference means allusions to real persons, places, events, objects, etc." (1986, p. 88). If the audience/reader recognizes such allusion with real or literary reference in the play, he will manage to see its double vision. Thus inserting literary or real-life reference in the play spins "the audience's attention to related persons, opinions, issues, 
situations that they have talked, thought, or experienced, and thus may enrich their vision, understanding and insight of the playwright" (Liang, 2010, p. 101).

9 Parts of Desire encompasses multiplicity of literary and real-life references that depict Raffo's vision of Iraq's cultural heritage. The play's first real reference to Iraq's culture immediately emerges even before reading the play, from the words of the title. The title, "Nine Parts of Desire", which refers to the nine women's narratives is taken from a Shiite proverb, believed to be said by Al imam Ali Ibn Abi Taleb. Being of an Iraqi origin, Raffo realizes that Shiite creed has been playing an important role in Iraq's long history. However, beyond its historic connotation, the title of the play, as Raffo herself confirmed is taken from Geraldine Brooks' biography Nine Parts of Desire: The Hidden World of Islamic Women (1994). Raffo, herself acknowledges the impact of Brooks' book on writing her play.

Real references are also paramount in the dramatization of real events, real names, and even real people in the play. Many real names and places that might be unfamiliar to non-Arab audience are dispersed in the play, like "Palestine Hotel", "Mount Lebanon" (Raffo, 2006, p. 38), "Fallujah", "Najaf", "the Golden mosque", "Ali Baba" (Raffo, 2006, p. 40). To enhance the connection between the audience/readers and the play's fictional world, an appendix of Arabic terms is added by the playwright, in the end of the book to help non-Arabs understand unfamiliar words. The play's stories interaction with reality heightens the audience's perception of the characters' memories and experience. This play also depicts real people as fictional characters, as Heather Raffo based her play on real people. She has admitted having interviews and sometimes transcripts to help personify her characters. She spent almost ten years building relationships with Iraqi women both in and outside Iraq, recalling the culture of her people's home. She asserts that preparing for composing 9 Parts of Desire involved "a process of spending time together, living, eating, communicating compassionately, and loving on such a level" (Raffo, 2006, p. x). However, Raffo (2006) adds that

With rare exception, none of the stories are told verbatim. Most are composites, and although each character is based on research, I consider all the women in my play to be dramatized characters in a poetic story. I liken it to songwriting -I listened deeply to what each woman said, what she wanted to say but couldn't, and what she never knew how to say. (p. x) 


\section{Sahar Abdel Khaleq Abbass}

Though Raffo's play has been based upon real interviews with real people, yet most of the characters' stories are composites and not literary personified. They are dramatized through juxtaposing reality with imagination, by foregrounding the metatheatrical nature of the play that helped actualize these characters' emotions, agony, and even identity. As William Egginton describes it, in a metatheatrical play "a distinction is recognized between a real space and another, imaginary one that mirrors it" (2012, p. 74)

The river in 9 Parts of Desire is another versatile example of literal and real-life reference, that is eloquently employed. According to Raffo, the metaphor of the ancient river, around which the play spins signifies a double vision. First, this river symbolizes "its central function connecting all of the women" (Raffo, 2006, p. 70), as the nine characters are linked in the play by their shared heritage. The metaphor of the river is also as Raffo asserts "a reminder of Iraq's heritage as the cradle of civilization. The river was both mythic and functional, a symbol of a life-giving source" (Raffo, 2006, p. 70). As early as the beginning of the play, Mullaya evokes the image of the river, the cradle of civilization, when she mourns: "without this river there would be no here/ here would be no beginning" (Raffo, 2006, p. 3). Iraq's heritage is drawn together by the ancient river into its present time and the present is melt in the cadence of its history. This river is "straight and fast" (Raffo, 2006, p. 4); its motion through Iraq exists as an emblem of connection and durability. For that reason, Mullaya yells: "the Garden of Eden was here/its roots and its rivers/ and before this Garden/ the chaos and the frightening" (Raffo, 2006, pp. 4-5). The history of civilization is surging through Raffo's reference to the river, and every one of her characters has a connection to its waters; "Layal's paintbrushes came out of the river; Huda's books and newspapers line the river; they become Nana's looted books and newspapers" (Raffo, 2006, p. 70); the Mullaya, too has "walked across it / Qurna, Eridu, Ur" (Raffo, 2006, p. 4). This river is the home of civilization, which unites everything. In this metatheatrical world made by Raffo, Iraqi heritage exists for the audience more than a reference to this history; it is as a source of inspiration, that invokes the power of the past, and widens the sight of the present. Here, the metatheatrical dramaturgy is "not just to connect, but also to ensure the transmission and reception of the underlying message of the play to [the] audience" (Taiwo, 2014, p. 148).

The use of Arabic in the play, is another metatheatrical technique that enables Raffo to get the audience's response. 9 Parts of Desire is replete with Arabic words that prompt non-Arabic reader's curiosity. Therefore, Raffo has added a glossary for Arabic terminology to consult, 
in the play. The use of more than one language in a literary work was first defined as heteroglossia by Russian literary critic Mikhail Bahktin. $\mathrm{He}$ viewed heteroglossia as "another's speech in another's language, serving to express authorial intentions but in a refracted way" (as cited in Al-Khalili, 2018, p. 223). Thus, Raffo has interspersed Arabic names and sentences with English to attain a compelling emotional impact on her audience. "The dawn call to prayer" (Raffo, 2006, p. 3), which is in Arabic, is the first sound heard in the play. Then Mullaya enters singing in Arabic "Chi Mali Wali" (Raffo, 2006, p. 3), the first line of a famous Iraqi song, which means "because I have no protector" (Raffo, 2006, p. 75). The embedded meaning of this line of the Arabic song summarizes the condition of the nine characters. Hence, the Arabic words stimulate the audience very early in the play, to share Mullaya's feeling of unsafety; a feeling that persists throughout the entire play. The last moments before her death, Layal also shifts between Arabic and English; "yaboo yaboo/ I'm fine I'm fine" (Raffo, 2006, p. 63), then we hear the sound of the fourth prayer call; "la ilaha illa allah" (Raffo, 2006, p. 63). Raffo' explicates that this phrase, which means there is no God, but Allah is "uttered upon witnessing or hearing of a sad or calamitous event" (Raffo, 2006, p. 78) to impress the audience. Mullaya, also yells in Arabic; "Baba oh Baba" (Raffo, 2006, p. 64), before she becomes fully immersed" (Raffo, 2006, p. 65) in the water. By exploiting the potential of Arabic in the play, Raffo highlights the perspective of these characters' stories. This metatheatrical strategy breaks the barrier between the characters and the audience and motivates the audience to mediate in the meaning of these Arabic words in English. Thus, the boundaries of language are detached, while the audience is reminded of the universality of these women's issues.

\section{2. Ceremonies and Rituals:}

Another metatheatrical pattern that remarkably emerges in 9 Parts of Desire is the use of ceremonies and rituals. Ceremonies and rituals imply cultural allusion that creates an interest in the play. Plays usually have different types of ceremonies, such as a funeral, prayers, a party, or a wedding. Hornby (1986) believes that ceremonies within plays are pervasive, that "it becomes difficult to find a play without a ceremony in it of some kind" (p. 49). The significance of rituals is insightfully expressed by Margaret Croyden, who believed that "ritual has always had a moral, religious, practical, or psychological significance, and has never existed for its own sake. Rites were a need" (as cited in Jing-xia, 2019, p. 39). 
Raffo's use of the Muslim calls to prayer reveals her proficiency in using this metatheatrical technique. Muslim calls to prayers illuminate the beginning of 9 Parts of Desire and are enriching throughout the course of the whole play. In her introductory notes, Raffo clarifies to her Western audience that for Muslims, "the call to prayer is heard five times a day: at dawn, at midday, in the afternoon, at sunset, and finally when the sky becomes dark and daytime is over" (Raffo, 2006, p. 3). In this play, Raffo chooses the five Muslim calls to prayer to theatricalize the play's shift of time and ideas. These calls to prayers are also employed five times through the unfolding of the play, which begins with the Dawn call to prayer and then ends with the final one. In fact, the use of prayer calls in the play supports the play's nonlinear structure. Each call to prayers in the play respectively announces a reflection of the playwright's vision, in an "attempt at creating a link between the fictional world of the [play] and [the] audience" (Taiwo, 2014, p. 150).

The play opens with the sound of Dawn prayer call, as if introducing Mullaya's ritual, which mourns the calamities of war, and grieves the destruction of her country's civilization. The midday call to prayer is heard when Umm Ghada is inviting the audience to witness the tragedy of the Amiriyya Shelter. The third call to prayer sounds right before Nana's first appearance, a woman who lives on selling the country's heritage as a commodity, and the fourth is heard with Layal's end, the first death of one of the nine characters. Almost before the play comes to its ending, and as soon as the Mullaya reappears, concluding her earlier ritual in an epilogue, "We hear the fifth and final call to prayer. Darkness, it is the end of the day's cycle" (Raffo, 2006, p. 65). The call to prayers not only keeps the nine narratives connected as one single unit but is also a metatheatrical shaking to keep the audience watchful and always interacting.

Mullaya's ritual is intellectually juxtaposed to almost every metatheatrical element in the play. Raffo describes Mullaya's mourning as "Mythic, celebratory, and inviting, this Mullaya's mourning is part of her ritual ablutions" (Raffo, 2006, p. 3). In her ritual, Mullaya, mourns the destruction of a spiritual landscape, that has been the land of civilization; "Early in the morning / I come to throw dead shoes into the river" (Raffo, 2006, p. 3). Mullaya ends her ritual with the lines, "late in the evening / I come to collect worn souls from the river" (Raffo, 2006, p. 65). The meditating mood of Mullayah's echoing mourning laments the killing of people, the destruction of civilization and how war may dehumanize and destroy generations. Mullaya as Magda Romanska (2010) argues, "is more symbolic figuration than character... In fact, 
what she mourns is the nation as a whole: its past, history, and culture...it is a source of national identity" (p. 218).

\section{3. A search for true self:}

"Role playing within the role" is a widely used metatheatrical tool. It usually occurs if a character because of insecurity about his identity and memories, is consciously or unconsciously, taking on a role other than his usual or true self. Hornby (1986) maintains that "role playing ...is particularly suited to the drama" (p. 68). Meanwhile, Callens (1998) argues, that metatheatre should promote a "specific heightening of the theatre's inherent doubleness, as fiction and reality, showing and telling, as a mind-broadening confrontation of the self with its Other, serving public and private interest" (p. 219). Role-playing shows "not only who the character is, but what he wants to be... [Usually] the role is closer to the character's true self than his every day, real personality" (Hornby, 1986, p. 67). Therefore, the employment of role playing in a play, empowers the representation of issues of human identity, and the relationship of the individual to his community.

Role playing within the play in 9 Parts of Desire is best dramatized in Huda, Layal and The American, whose blurred personalities are unveiled by their dualistic characters. Huda, "an Iraqi exile in her seventies, now living in London" is aware of her dilemma (Raffo, 2006, p. 18). Though she has been "always political" (Raffo, 2006, p. 19), she is rejecting this role now, claiming that she "couldn't march with anyone who was pro- Saddam" (Raffo, 2006, p. 19). Kelly Oliver views that "Our inaccuracies and false beliefs ... can reveal something true about our desires and fears" (2004, p. 85). Huda's words embody her troubled diverse feelings, she cannot decide which role she should play; "I have my doubts about American policy, / still I prefer chaos to permanent repression" (Raffo, 2006, p. 19). She is also uncertain about her identity; "I am in a period of disheartenment everywhere .... I don't know what to do with myself now, I have doubts, yeah, well/ about my whole life" (Raffo, 2006, p. 39). Feeling physically safe away from her country is not sufficient to stop Huda's feeling of perplexity.

On the other hand, Layal, the artist, appears with a double identity. She could only have a secure life by playing two different roles. She cooperates with the regime but at the same time opposes it. Operating on a survival mode, Layal strives to preserve a consistent self-image, for her own self, and for the others around as well. She has the feeling of being hooked by the diverging roles she is playing, "being a victim, collaborator, and critic of [her] government" (Romanska, 2010, p. 221). Layal has a strong feeling of being victimized, because motivated by her 


\section{Sahar Abdel Khaleq Abbass}

need to stay secure, she involuntarily chooses to have a good relationship with the regime. Hornby (1986) observes that "voluntary role playing within the role is the most metadramatic type" (p. 73). Layal puts her life at risk when she voluntarily chooses to change the role she is playing and opposes the war and the regime. Her fragmented words scattered throughout the play reflect the dilemma she is entrapped in; she says, "And two hundred more .../ risking everything to take my place / without my legs / buried in the backyard" (Raffo, 2006, p. 62). When Layal is closest to death, she breaks down, and then speaks outwardly nonsense words that depict her divided self.; "third bomb boil the people / I don't want freedom / Mullaya why are you here?.../yaboo yaboo/ I'm fine I'm fine" (Raffo, 2006, p. 63).

The unnamed American's story is also scattered throughout the play, thus reflecting her torn-apart identity. Like Raffo herself, The American lives in America, while the rest of her family live in Iraq. Romanska (2010) wrote "Watching the bombs come down on her family neighborhood, the American is stunned by her own sense of alienation: She has grown to identify herself as an American, and now, she is asked to view herself as the other, the enemy" (p. 230). Raffo, herself admits having that feeling of double identity, saying, "As an American with a father who was born in Iraq, I naturally live on both sides of the issues" (Raffo, 2011, para. 7). In her self-conscious words, The American speaks to the audience of the way her experience differs within the American culture. Her divided identity between the two communities is strengthened when she narrates, "A woman actually turned to me... she said/ 'The war it's all so heartbreaking.'/ She was getting a pedicure. / I was getting a fucking pedicure... Why don't we count the number of Iraqi dead?" (Raffo, 2006, p. 49) Though she believes the country in which she lives intentionally destroys the country where her family lives, The American is helpless; "don't tell me /they didn't know their job /not with smiling/ every photo /they were / smiling" (Raffo, 2006, p. 48). Her distorted identity is more intensified in her comment on her uncle's phone call from Iraq; "He called to say / he was sorry /can you believe that? / Sorry for my great city" (Raffo, 2006, p. 56). The same feeling is reinforced when she is worried about her family members in Iraq, and begins calling their names on the phone, "I love you...Behnam/ Rabab/ Ammar/ Bashshar..." (Raffo, 2006, p. 59). When she recalls the names of her family as a kind of mourning in an epilogue, The American is playing the role of Mulayya, who mourns the whole nation in both her prologue and epilogue.

Huda, Layal and the American are suffering from conflicting identity. They have difficulty figuring out what they really are and what 
they really want. Having uncertain identity and being confused about how they are supposed or expected to act, lead them to play more than one role. "The double ...vision created by the dizzying shifting" (Liang, 2010, p. 103) of these characters' rationales engages the audience in their dilemma. It motivates the audience to keep moving backward and forward in the play in order to understand the characters' perspectives. Thus, Raffo manages to establish a highly effective dramaturgical communication with the audience through skillfully employing roleplaying within the role.

\section{4. You should share my world: self-reference in the play.}

According to Hornby (1986), self-reference "is the most extreme, intense form of metadrama" (p. 117). "With self-reference, the play directly calls attention to itself as a play, an imaginative fiction" (Hornby, 1986, p. 103). Self-reference occurs in a play when the characters are self-conscious and "tend to improvise, thus usurping the role of the playwright" (Rosenmeyer, 2002, p. 88). Then, there will be "a shift in perception that turns the field of thought inside out. What had been background is foregrounded, and vice versa" (Hornby, 1986, p. 116). Smith (2015) maintains that "the context and the conventions within which the play is presented, both in terms of its momentary performance and of the culture in which the play is presented" (p. 16), is a part of this background. Hence "redirecting the audience's attention, even for an instant, from the foreground of the performance to the background...is self-referencing" (Smith, 2015, p. 16).

In 9 Parts of Desire, Raffo's nine characters are all aware of their own theatricality. Throughout the unfolding of the play, each woman narrates her own story in accordance with her own laws, engaging the audience with active listening and observation. Accordingly, the play intensifies not merely the self-consciousness of the characters but also the involvement of the audience. Raffo's nine characters appear individually, one after the other, speaking alone and aloud, uninterrupted by each other, smoothly changing from one to another, but not following linearity. Challenging traditional dramatic techniques, Raffo portrays the narratives of her nine characters without following linearity, in which the events of the play unfold in the normal logical progression. The play does not have a dramaturgical course that plainly signifies its beginning, its middle, or its end. Haney William maintains that "the lack of logical movement" in a play is a metatheatrical feature (as cited in Keshavarz, 2012, p. 141). Convinced that "the plot is a product of the author's own imagination and not rooted in a fixed tradition" 


\section{Sahar Abdel Khaleq Abbass}

(Rosenmeyer, 2002, p. 88), and that the narratives of her characters do not require a traditional structure, Raffo contends:

I had no compassion for, or need for, or desire for anything linear, and I was angry when anyone wanted to change my structure ... producers, directors, writers wanted to know that it had a beginning, a middle, and an end, they wanted to know where it was going, what time frame each character was in. ... I always go back to Ntozake Shange's nonlinear For Colored Girls, which I picked up and said 'that is so female, nonlinear,' and it was the only play to hit me on that level. (as cited in Russell, 2008, p. 116)

Raffo also asserts that her use of the technique of non-linearity, is a duplication of Ntozake Shange' s For Colored Girls Who Have Considered Suicide/When the Rainbow Is Enuf (1974), which depicts seven black women, telling their stories on stage.

Each character in Raffo's appears alone in different times and situations without notice. Only the character's way of wearing the abaya is utilized to notify the audience/reader with the shift of characters. Raffo's use of the abaya has mostly been acknowledged by reviewers and critics in their recognition of the theatricality of 9 Parts of Desire. The abaya is "a traditional black robe-like garment that has long been worn by both women and men in Iraq" (Raffo, 2006, p. 71). All the 9 characters of the play wear the abaya, representing a unifying image that signifies one common identity with Iraq. Furthermore, the abaya has a metatheatrical function in the play, as it is used by Raffo "to move from character to character" (Raffo, 2006, p. 2). Raffo distinguishes the identity of each woman in the play by her way of wearing the abaya. Thus, even without uttering a word, these characters' use of the abaya connotes their theatricality, and makes the audience shift from the foreground, the embedded meaning of the dialogue to also identify the play's dramaturgy, or its background. When the Mullaya enters, she is wearing the abaya traditionally, then the Mullaya is transferred into Layal, by wearing "the abaya loosely hanging off her shoulders like a dressing gown or painting smock" (Raffo, 2006, p. 6). Amal is a Bedouin, who has been seeking out a faithful loving husband, "wears the abaya fastened behind her head / and flowing voluptuously about her body" (Raffo, 2006, p. 11). The Doctor, "desperate to keep her hands clean", "washes her hands, then dries them on the abaya" (Raffo, 2006, p. 20), hoping to clean Iraq of the poisonous environment caused by the war. For Sameera, the little girl, the abaya is a toy, so she is "wrapping it around her head like long luxurious hair and other times bundling it up to be her baby doll" (Raffo, 2006, p. 22). 
Meanwhile, Umm Ghadda "lets the abaya fall [like] a black hole" (Raffo, 2006, p. 28) in the bomb shelter, where she lost her family. Because she is an elderly, Nanna puts the abaya "traditionally over her head so only her face and hands remain showing" (Raffo, 2006, p. 41). The audience then is required to guess the intended reference of each change of the abaya. Thus, for every move from one character to the other, "the audience must have stopped, shifted its focus from foreground to background, identified the [character] playing the role, and then shifted back to the foreground of the play" (Smith, 2015, p. 17). This kind of self-reference is sufficient to turn the play metatheatrical.

The characters in 9 Parts of Desire also share their monologues with the audience by speaking in the first person using direct speech. "The author's direct address to the audience, [is] clearly an old used metatheatrical technique" (Smith, 2015, p. 10), which has its metatheatrical power "not only to communicate about [the] play world but also to create that world with every word" (Stephenson, 2006, p. 117). In 9 Parts of Desire, each character introduces her story, and then there is only one single character always on the stage, narrating a part of her story. Self-reflection is embedded in Umm Ghada's dialogue, who revisits the Amiriyya bomb shelter to remind the audience of its haunting history. Aware of her own theatricality, she uses the firstperson pronouns and addresses the audience. Umm Ghada begins her story by introducing herself; "I named my daughter Ghada. / Ghada means tomorrow. / So I am Umm Ghada, Mother of Ghada." (Raffo, 2006, p. 28). She says her daughter Ghada was among the victims. "so I am Umm Ghada, Mother of Tomorrow. / My full name is dead with them" (Raffo, 2006, p. 31). Raffo manipulated this self-reference to enable her character to narrate how her present self is affected by her past, the loss of her family. However, Umm Ghada clings to the future, represented in her daughter's name, Tomorrow. Umm Ghada directly asks the audience to bear witness to this carnage for the future generations, when she says: "Here is guest book they all sign, / your name will be witness too. / $L a$, I must show it to you first. Ta'al" (Raffo, 2006, p. 29). The constant use of the 'you' and 'your' pronouns, in addition to the use of Arabic words are strategies that pursue engaging the audience, in the play. The more direct the form of speech, the more consciously is the effect on the audience.

The embedded self-reference with Sameera, the little Girl, is also compelling for the audience. Sameera directly speaks to the audience, with broken English, hinting how her present is affected by the arrival of 


\section{Sahar Abdel Khaleq Abbass}

the American invasion. She says, "I have not been to school/ since America came" (Raffo, 2006, p. 23). She also tells the dreadful happenings of her father's loss in the past and her fear of losing her mother soon. She says: "I remember some mens came to our house/ to take my father.../I have not seen him since I was seven" (Raffo, 2006, p. 27). Nana also uses direct speech claiming that she can narrate Iraq's history because she has "lived through twenty-three revolutions" (Raffo, 2006, p. 42). Her description of the looting and absence of stability in Iraq in the present time, in direct speech, forces the audience to keep shifting from the embedded meaning of her narration to the art of the play. She says she saw the burning of "All/ National Archives,/Qur'anic Library/ all/ I saw a map/ they knew what to take/ they were told what to take/..../ Our history is finished" (Raffo, 2006, p. 43). Using "You" to sell Layal's painting, Nana determinedly conveys Raffo's message of the unknown future for Iraq to the audience; she says: "You must buy, buy / .... I have to sell it / I have to eat" (Raffo, 2006, pp. 67-68). The audience's role is again featured when Amal, searching for love and freedom, concludes her story with intimate words that directly address the audience and request some sympathy. She says: "I want to be like you .... oh really I love you, like a sister I love you... Don't leave, stay with me... Tell me what you think/ What should I do? (Raffo, 2006, p. 18) These embedded representations prepare a move toward not only the audiences' identification with the characters, but also observing the metatheatrical skill of the play.

Raffo's "metatheatre ...is intentionally exposed through dialogic techniques bidding for attention. The audience is a receptive but junior partner, picking up metatheatrical cues embedded in the performance text" (Stephenson, 2006, p. 122). Like in Brechtian Epic theatre, which enforces the audience's reaction to the drama by using direct speech, Raffo does not leave her audience stay aside, merely watching the play. As she asserts; "The audience plays a vital role in the show with each ...character speaking directly to them in English as if they were a trusted western friend" (Raffo, 2011, para. 9). The audience is always reminded that the play's characters are fictional personalities and not actual people. Thus, through playfully employing self- reference in 9 Parts of Desire, Raffo manages to create a positive relationship between the fictional world of her characters and the audience. The audience keeps shifting from the foreground of the monologues into the background, exploring both the embedded meaning of the dialogues and its self-referential dramaturgy. According to Anne Ubserfeld, "Non-dialogues monologues and soliloquies - are by nature dialogical, ... because they presuppose, by virtue of their being theatre, a present but silent listener, 
the spectator" (as cited in Fyffe, 2010, p. 20), but at the same time they include another speaker. This other speaker in 9 Parts of desire is Raffo herself, whose characters' self-awareness conveys her vision of the reality of Iraq's predicament. Self-reflection in Raffo's play operates as an instinctive model to redirect conversation and cultural understanding. As Nadia Anwar asserts: "A piece of performance or a dramatic enactment attain its meaning in the audience's perception through certain strategies ...which a playwright ... applies in order to manipulate ideas, opinions, images, and information" (2014, p. 76).

\section{Conclusion}

While the examples chosen from Raffo's play display her high artistry of metatheatrical dramaturgy, the play itself is replete with much more. 9 Parts of Desire demands "a deeper awareness and should be evaluated by destructing the conceptual boundaries [of]the standard norms" of theatre (Keshavarz, 2012, p. 137). Through brilliantly employing metatheatrical techniques, Raffo dramatizes Iraqi genuine narratives that feature a diversity of intricate issues, heritage, war, struggle, and anguish. However, while calling for "an acknowledgment of a history that has been omitted", she "places the responsibility for change in the hands of her audience" (Lackey, 2019, para. 4). Raffo's audience is not permitted to relax with the traditional norms of theatre, as her technique smashes down its conventional rules. She "breaks 'the fourth wall', which is an invisible, imagined wall that separates the actors from the audience" (Jing-xia, 2019, p. 40). As Lahr (2004) describes her technique, "The shifts-mystical to secular, old age to youth, Iraqi to American - keep an audience at attention and at arm's length" (para. 4) . Raffo's employment of metatheatrical techniques in the play, has turned the audience into characters in the same play, sharing the same destiny of the play's characters. The multidimensional metatheatrical methods Raffo uses not only upsurge the high artistry of the play but also locate it both culturally and politically. 


\section{Sahar Abdel Khaleq Abbass}

\section{References}

Abel, L. (2003). Tragedy and Metatheatre: Essays on Dramatic Form. New York and London: Holmes \& Meier.

Al-Khalili, R. K. (2018). The Application of Bakhtin's "Heteroglossia" to Tennessee Williams's A Streetcar Named Desire'. Advances in Language and Literary Studies, 9(6), 223-228.

Anwar, N. (2014). Modulation of Human Distance: The Case of Wole Soyinka's King Baabu'. Humanities \& Social Studies Review, 3(2), 73-85.

Anwar, N. (2016). Playing to the Audience - Newspaper- dawn.com. https://www. dawn.com /news/1297440. (Retrieved on 2 May, 2020)

Callens, J. (1998). Discovering Utopia: Drama on Drama in Contemporary British Theatre. Estudios Ingleses de la Universidad Complutense, 6, 211- 221.

Crow, B. (2002). 'African Metatheater: Criticizing Society, Celebrating the Stage'. Research in African Literatures, 33 (1), 133-143.

Egginton, W. (2012). How the world became a stage: Presence, theatricality, and the question of modernity. NY, United States: SUNY Press.

Fyffe, L. (2010). Political Theatre Post 9/11: The Age of Verbatim, of Testimony, and of Learning from Fictional Worlds. (Doctoral dissertation, University of Ottawa (Canada).

Hornby, R. (1986). Drama, Metadrama and Perception. London and Toronto: Associated University Presses.

Jing-xia, C. (2019). Understanding Metatheatre. US-China Foreign Language, 17 (1), 35- 42. doi:10.17265/1539-8080/2019.01.005 (Retrieved on June 3, 2019)

Keshavarz, M. (2012). Beckett's Metatheatrical Philosophy: a Postmodern Tendency Regarding Waiting for Godot and Endgame'. Mediterranean Center of Social and Educational Research, 3(3), 137- 144.

Lackey, H. (2019). 9 Parts of Desire: Raffo's Representation of Iraqi Women. Cultural Consent, https://www.culturalconsent.com/home/2019/3/1/9- parts-of-desire-raffosrepresentation-of-iraqi-women (Retrieved on 5 January, 2020)

Lahr, J. (2004). The Critics: the Theater: the Fury and the Jury: Women, and Men, Make Themselves Heard. The New Yorker, 80 (34), 136-138.

Liang, F. (2010). Metadrama and Themes in Stoppard's Rosencrantz and Guildenstern are Dead. Canadian Social Science, 3 (3), 99-105.

Oliver, K. (2004). Witnessing and Testimony. Parallax, 10 (1), 78-87.

Pavis, P. (1998). Dictionary of the Theatre: Terms, Concepts, and Analysis. Toronto and Buffalo: University of Toronto Press.

Raffo, H. (2006). Heather Raffo's 9 Parts of Desire. Evanston, Illinois: Northwestern University Press.

Raffo, H. (2011). Heather Raffo, Actor/ Playwright. https://heatherraffo.com/projects/nine-parts-of-desire/ (Retrieved on 5 June, 2017)

Romanska, M. (2010). 'Trauma and Testimony: Heather Raffo's 9 Parts of Desire'. Alif: Journal of Comparative Poetics, 30, 211-240.

Rosenmeyer, T. G. (2002). 'Metatheater': An Essay on Overload. Arion: A Journal of Humanities and the Classics, 10 (2), 87-119. 


\section{Upsurges of Metatheatrical Dramaturgy in Heather Raffo's 9 Parts of Desire}

Russell, S. B. (2008). The Revolution Continues: A New Actor in an Old Place. (Doctoral dissertation, Florida State University (USA).

Smith, R. L. (2015). Metatheatre in Aeschylus' Oresteia. Athens Journal of Philology. 2(1), 9-20.

Stephenson, J. (2006). Meta-enunciative Properties of Dramatic Dialogue: A New View of Metatheatre and the Work of Slawomir Swiontek. Journal of Dramatic Theory and Criticism, 21(1), 115-128.

Taiwo, E. F. (2014). Deconstructing the "Fourth Wall": Metatheatricality in Plautus' Miles Gloriosus and Osofisan's Tegonni'. Canadian Social Science, 10 (5), 146-152. 